\title{
Effects of physical and chemical factors on Ephemeroptera (Insecta) assemblages in an urban river of the eastern Colombian Llanos
}

\author{
Jose Ismael Rojas-Peña ${ }^{1,4}$; Jesús Manuel Vásquez-Ramos² ; Luis Gonzalo Salinas-Jiménez ${ }^{3}$; \\ Diana Paola Osorio-Ramirez ${ }^{1,5}$ \& Clara Inés Caro-Caro ${ }^{1,6}$
}

\footnotetext{
1 Universidad de los Llanos (UNILLANOS), Instituto de Ciencias Ambientales de la Orinoquia Colombiana (ICAOC), Grupo de Investigación en Gestión Ambiental Sostenible (GIGAS). Villavicencio, Meta, Colombia.

2 Universidad de los Llanos (UNILLANOS), Facultad de Ciencias Básicas e Ingeniería (FCBI), Departamento de Biología y Química, Grupo de Investigación Evaluación, Manejo y Conservación de Recursos Hidrobiológicos y Pesqueros (GIREHPES). Villavicencio, Meta, Colombia. ORCID: http://orcid.org/0000-0003-1465-9407. E-mail: jvasquez@unillanos.edu.co

3 Universidade Federal de Viçosa (UFV), Departamento de Entomologia (DDE). Viçosa, MG, Brasil. ORCID: http://orcid.org/0000-0002-8973-4996. E-mail: biobaetodes@gmail.com

${ }^{4}$ ORCID: http://orcid.org/0000-0002-4005-0825. E-mail: jose.rojas.pena@unillanos.edu.co (correspondence author)

${ }^{5}$ ORCID: http://orcid.org/0000-0002-7643-3369. E-mail: dosorio@unillanos.edu.co

${ }^{6}$ ORCID: http://orcid.org/0000-0003-1589-6535. E-mail: clarainescaro@unillanos.edu.co
}

\begin{abstract}
The mayflies are insects widely known as indicators of aquatic quality in freshwater systems, they are abundant and diverse in tropical streams. In this study, it was determined the influence of physical, chemical and bacteriological characteristics on the Ephemeroptera assembly in a period of low precipitation in the 0coa river of Meta department. There were 5,332 nymphs belonging to 4 families, 10 genera and 3 species. Three new genera records and one species are presented for Meta: Cloeodes, Zelusia, Lumahyphes and Americabaetis alphus. The genera Camelobaetidius and Varipes were found associated with conditions of contamination by organic matter and water mineralization. Likewise, Americabaetis, Thraulodes, Lumahyphes and Tricorythodes were associated with contamination conditions, especially with nitrites and nitrates. Nanomis, Cloeodes and Zelusia showed greater sensitivity to the contamination condition and were related to high percentages of dissolved oxygen in the water and they were in the sampling stations of the upper part in the river. It is important to mention that there were not Ephemeroptera in most of the stations associated with the urban area. That reflects their high sensitivity to polluting conditions at low precipitation period.
\end{abstract}

Keywords. Water quality; Mayflies; Pollution; Distribution; Orinoquia.

\section{INTRODUCTION}

The effect of pollution on aquatic ecosystems by anthropogenic impacts (e.g., irrigation of crops, urbanization, domestic and industrial discharges, and channelization) are the main cause of loss of their natural characteristics (Mallin \& Cahoon, 2003; Blann et al., 2009; Tanaka et al., 2016). Those impacts generate a homogeneous environment and significantly affect the stability of aquatic communities (Bauernfeind \& Moog, 2000), and deteriorate the water resource for society and the environment (WWAP, 2017). Since these activities can change the water quality, the managements have been used the physicochemical aspects of water to monitor and evaluate the ecological condition of the streams (Ramírez \& Viña, 1998). Last years, they have integrated the organisms as bioindicators and physicochemical variables (Prat et al., 2009).

Initially, the physical and chemical indices were used to evaluate the water quality, however they have several limitations to respond and discriminate against different human activities (Sharifinia et al., 2016). Then it was implemented the use of aquatic macroinvertebrates. They have been recognized as good bioindicators of water quality due to the ability to respond to different types of environmental disturbances (Hodkinson \& Jackson, 2005; Miranda, 1987; Prat et al., 2009; Sharifinia et al., 2016; Springer, 2010). Nevertheless, the taxonomic and ecological complexity of aquatic macroinvertebrates are high. Therefore, it has been suggested the analysis of a single representative biological group like Ephemeroptera, which presents different levels of tolerance to en- 
vironmental disturbances and contamination (Arimoro \& Muller, 2010; Buss \& Salles, 2007; Hubbard \& Peters, 1978; Savić et al., 2011; Shimano et al., 2013; Zedková et al., 2014). Mayflies have been widely cited as bioindicators in monitoring programs owing to: (1) their high abundance and diversity; (2) have a broad geographical distribution; (3) their well-known taxonomy and based mainly on immature stages; (4) their capacity for colonize variety of substrates; (5) and their good taxonomic resolution in the neotropical region (Barber-James et al., 2008; Buss \& Salles, 2007; Edsall, 2001; Forero-Céspedes \& ReinosoFlórez, 2013; Menetrey et al., 2008; Moog et al., 1997; Prat et al., 2009; Souto et al., 2011).

Colombia is recognized worldwide for its water wealth, specifically the Eastern region with Orinoco and Amazon basins, shared with several countries (Roldán \& Ramírez, 2008). However, they are suffering the impact of population growth with the urbanization and demand for water resources for the cities (Correa, 2014). Among these is the Ocoa river, which starts and ends within the municipality of Villavicencio and collects water from 42 tributaries; it is a source of water for domestic consumption, agricultural, forestry and mining activities, as well as being $80 \%$ recipient of the wastewater discharges (Osorio-Ramírez et al., 2015). Based on the above, the objective of this research was: 1 . Determine the diversity of Ephemeroptera assembly and 2. Determine the influence of physical, chemical and bacteriological characteristics on the Ephemeroptera assembly in a period of low rainfall in the Ocoa river, department of Meta, Colombia.

\section{MATERIAL AND METHODS}

Study area: The Ocoa river basin rises in the southwestern municipality of Villavicencio (Meta department) in the rural settlement Samaria (1,155 m.a.s.l.). It flows east to Guatiquía river in the Murujuy sector, between the villages El Guamo and Indostan (225 m.a.s.l.). It covers longitudinally $54.89 \mathrm{~km}$ with an area of 28,290 ha (Fig. 1). The climate regime of the basin presents a precipitation among 2,700 mm/year in low zone to 5,000 mm/year in the high zone. Likewise, the atmospheric humidity and temperature varies from the low zone $\left(79 \%, 19.5-33.5^{\circ} \mathrm{C}\right)$ to the upper zone $\left(84 \%, 15.5-30^{\circ} \mathrm{C}\right.$ ) (Osorio-Ramírez et al., 2015).

Collection of specimens: The Ephemeroptera collections were made in the low rainfall period, at 15 sampling stations (a representative reach of the Ocoa river and some tributaries: $100 \mathrm{~m}$ ) that have variations in land use, vegetation cover and discharges (Table 1). The collection of organisms was made with surber sampler (300 $\mu \mathrm{m}, 900 \mathrm{~cm}^{2}$ area) (Domínguez et al., 2009). 15 subsamples were randomly taken in each sampling station on pebble substrate. In the laboratory, the organisms were preserved in $90 \%$ alcohol and were identified at the lowest taxonomic level using the keys and descriptions of Domínguez et al. (2009) and Domínguez et al. (2006).

\section{Physical, chemical and bacteriological variables of} water: At each sampling station, 5 variables were measured in situ: $\mathrm{pH}$ ( $\mathrm{pH}$ units), dissolved oxygen ( $\left.\mathrm{mg} / \mathrm{L} \mathrm{O}_{2}\right)$, temperature $\left({ }^{\circ} \mathrm{C}\right)$, electrical conductivity $(\mu \mathrm{S} / \mathrm{cm})$ and flow $\left(\mathrm{m}^{3} / \mathrm{s}\right)$. Fourteen variables were measured ex situ: ammonium (mg/ $\mathrm{L} \mathrm{NH}_{3}$ ), bicarbonates $\left(\mathrm{mg} / \mathrm{L} \mathrm{HCO}_{3}\right), \mathrm{COD}$ $\left(\mathrm{mg} / \mathrm{L} \mathrm{O}_{2}\right), \mathrm{BOD}_{5}\left(\mathrm{mg} / \mathrm{L} \mathrm{O}_{2}\right)$, iron $(\mathrm{mg} / \mathrm{L} \mathrm{Fe})$, nitrates $(\mathrm{mg} / \mathrm{L})$ $\left.\mathrm{NO}_{3}{ }^{-}\right)$, nitrites $\left(\mathrm{mg} / \mathrm{L} \mathrm{NO}_{2}\right)$, orthophosphates $\left(\mathrm{mg} / \mathrm{L} \mathrm{PO}_{4}\right)$, total dissolved solids (ppm STD), sulfates $\left(\mathrm{mg} / \mathrm{L} \mathrm{SO}_{4}\right)$, turbidity (UNT), surfactants (mg/L SAAM), zinc (mg/L Zn) and total coliforms (NMP/100 ml), analyzed by the ANALQUIM laboratory, certified by the Instituto de Hidrología, Meteorología y Estudios Ambientales (IDEAM) in Colombia. The Organic Matter Contamination

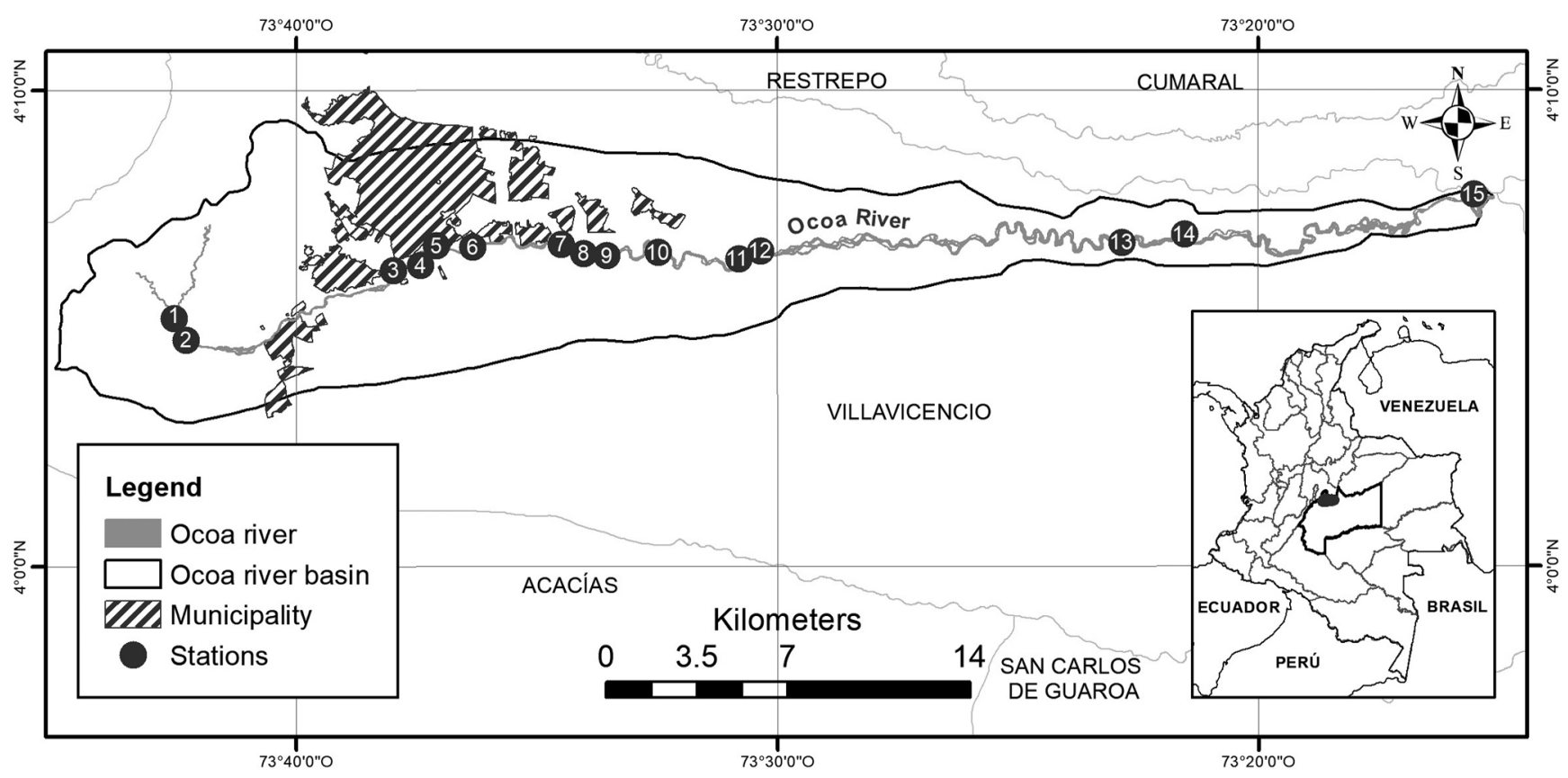

Figure 1. Geographical location of the 0 coa river basin and sampling stations. 
Table 1. Description of the 0coa river sampling stations.

\begin{tabular}{|c|c|c|c|c|}
\hline $\begin{array}{l}\text { Sampling } \\
\text { Station }\end{array}$ & Name & Coordinates & $\begin{array}{l}\text { Altitude } \\
\text { (m.a.s.l.) }\end{array}$ & Station's characteristics (vegetation cover, land use, dumping) \\
\hline 1 & Union Q/da Blanca y río Ocoa & $04^{\circ} 05^{\prime} 13.3^{\prime \prime} \mathrm{N}, 73^{\circ} 42^{\prime} 32.6^{\prime \prime} \mathrm{W}$ & 532 & Dense forest. Scattered residential and livestock. Domestic dumping of farms and neighboring houses. \\
\hline 2 & San Luis de 0 coa & $04^{\circ} 04^{\prime} 45.8^{\prime \prime} \mathrm{N}, 73^{\circ} 42^{\prime} 18.2^{\prime \prime} \mathrm{W}$ & 504 & Wooded pastures. Residential. Domestic dumping of farmhouses, poultry farmers and use of water for recreation. \\
\hline 3 & Puente caído & $04^{\circ} 06^{\prime} 13.5^{\prime \prime} \mathrm{N}, 73^{\circ} 37^{\prime} 58.9^{\prime \prime} \mathrm{W}$ & 419 & $\begin{array}{l}\text { Urban areas and clean pastures. Residential. Domestic and industrial discharges such as: oil company, thermo-electric } \\
\text { power plant, fish farms, car washes and pig beneficiary plant. }\end{array}$ \\
\hline 4 & Before caño Buque & $04^{\circ} 06^{\prime} 19.6^{\prime \prime} \mathrm{N}, 73^{\circ} 37^{\prime} 25.3^{\prime \prime} \mathrm{W}$ & 420 & Urban areas and clean pastures. Residential. Industrial and domestic dumping and car washes. \\
\hline 6 & Bridge Chorillano & $04^{\circ} 06^{\prime} 42.9^{\prime \prime} \mathrm{N}, 73^{\circ} 36^{\prime} 20.5^{\prime \prime} \mathrm{W}$ & 399 & Urban areas and clean pastures. Residential. Domestic dumping, car washes, restaurants and grills. \\
\hline 7 & Before caño La Cuerera & $04^{\circ} 06^{\prime} 42.3^{\prime \prime} \mathrm{N}, 73^{\circ} 34^{\prime} 19.4^{\prime \prime} \mathrm{W}$ & 381 & Urban areas and clean pastures. Residential. Industrial and domestic dumping. \\
\hline 8 & Caño La Cuerera & $04^{\circ} 06^{\prime} 50.0^{\prime \prime} \mathrm{N}, 73^{\circ} 34^{\prime} 20.0^{\prime \prime} \mathrm{W}$ & 381 & Urban areas and clean pastures. Residential. Industrial and domestic dumping, close to an old sanitary landfill. \\
\hline 9 & After caño La Cuerera & $04^{\circ} 06^{\prime} 41.0^{\prime \prime} \mathrm{N}, 73^{\circ} 34^{\prime} 14.4^{\prime \prime} \mathrm{W}$ & 377 & Clean / managed pastures. Residential. Industrial and domestic dumping, close to an old sanitary landfill. \\
\hline 10 & Before caño Maizaro & $04^{\circ} 06^{\prime} 30.5^{\prime \prime} \mathrm{N}, 73^{\circ} 33^{\prime} 43.8^{\prime \prime} \mathrm{W}$ & 374 & $\begin{array}{l}\text { Clean / managed pastures. Residential and agricultural Domestic discharges associated with farms near the river and } \\
\text { livestock activities. }\end{array}$ \\
\hline 11 & Caño Maizaro & $04^{\circ} 06^{\prime} 30.0^{\prime \prime} \mathrm{N}, 73^{\circ} 30^{\prime} 40.0^{\prime \prime} \mathrm{W}$ & 345 & $\begin{array}{l}\text { Clean / managed pastures. Residential, agricultural and livestock. Domestic dumping and waste of tires, plastics, } \\
\text { mattresses and paper from the city. }\end{array}$ \\
\hline 12 & After caño Maizaro & $04^{\circ} 06^{\prime} 32.9^{\prime \prime} \mathrm{N}, 73^{\circ} 30^{\prime} 39.2^{\prime \prime} \mathrm{W}$ & 345 & $\begin{array}{l}\text { Clean / managed pastures. Agricultural and livestock. Domestic and industrial dumping and livestock activities near } \\
\text { the river. }\end{array}$ \\
\hline 13 & Discharge Ecopetrol-Apiay & $04^{\circ} 06^{\prime} 48.4^{\prime \prime} \mathrm{N}, 73^{\circ} 22^{\prime} 50.0^{\prime \prime} \mathrm{W}$ & 259 & Clean / managed pastures. Agricultural and livestock. Domestic and industrial dumping associated with the oil sector \\
\hline 14 & Alcaraván & $04^{\circ} 06^{\prime} 59.0^{\prime \prime} \mathrm{N}, 73^{\circ} 21^{\prime} 31.8^{\prime \prime} \mathrm{W}$ & 276 & $\begin{array}{l}\text { Weeds / stubble. Agricultural. Domestic and industrial dumping and changes in the channel due to the transit of } \\
\text { heavy-duty cars. }\end{array}$ \\
\hline 15 & Mouth of 0 coa river & $04^{\circ} 07^{\prime} 48.8^{\prime \prime} \mathrm{N}, 73^{\circ} 15^{\prime} 30.1^{\prime \prime} \mathrm{W}$ & 241 & Heterogeneous crops. Agricultural. Domestic dumping of farms and water collection for rice and oil palm crops. \\
\hline
\end{tabular}

Index (ICOMO) was applied (Ramírez et al., 1997), considering that the main sources of pollution are generated by wastewater from urbanization, which flow directly and indirectly into the Ocoa river.

Data Analysis: The taxonomic composition and abundance of the Ephemeroptera were determined for sampling station. Richness (OD), Shannon-Wiener diversity (1D) and Simpson dominance (2D) metrics were calculated in order to know the degree of equity and dominance in the sampling stations by means of effective numbers of genera or Hill numbers (Hill, 1973; Jost, 2006). For this, we used the PAST program (Hammer et al., 2009) and the Real Statistics Resource Pack software (Release 6.8) (Zaiontz, 2020). In order to identify the physical and chemical variables that significantly affect the richness (OD) of Ephemeroptera, Generalized Linear Model (GLM) were tested and fitted to data (Model = quasi-Poisson, link $=$ Log function, test $=$ Chi square) (Dunn \& Smyth, 2018). Previously, the collinearity of predictor variables was analyzed with Pearson's linear correlation (variables with $|r|>0.7$ were omitted to compensate for collinearity) (Dormann et al., 2013). In this way, the chosen variables for analysis were flow, temperature, dissolved oxygen, conductivity, nitrites, nitrates, phosphorous, total coliforms and ICOMO. Models were constructed with all possible combinations of parameters and they were considered adequate and retained when differing less than 2 AIC from the model with the lowest (best) AIC value (Dos Reis Oliveira et al., 2020). The R2 values were used to measuring the goodness of fit of GLM's (Crawley, 2007; García, 2020). These analyses were performed in RStudio (RStudio Team, 2015), using the packages vegan (Oksanen et al., 2019) for GLM analysis and MuMIn version 1.43.17 (Bartoń, 2020) for model selection.
In addition, direct ordination methods were explored to analyze the relationships between biotic variation and the environmental variables. Redundancy analysis (RDA) was adopted after detrended correspondence analysis (DCA) performed showing that lengths of former four axes were less than 2. Environmental variables data was standardized to z-cores. Forward selection procedure was realized in order to select the most important variables (Blanchet et al., 2008). Biotic data were submitted to Hellinger transformation (Peres-Neto et al., 2006). The statistical analyses were performed with vegan (Oksanen et al., 2019) and adespatial (Dray et al., 2019) packages in RStudio (RStudio Team, 2015).

\section{RESULTS}

Taxonomic composition of the Ephemeroptera assembly: We quantified 5,332 nymphs belonging to 4 families, 10 genera and 3 species (Americabaetis alphus Lugo-Ortiz \& McCafferty, 1996, Camelobaetidius edmundsi Dominique et al., 2001, Nanomis galera LugoOrtiz \& McCafferty, 1999). The most abundant families were Baetidae (61.96\%) and Leptohyphidae (31.12\%), and the least abundant were Leptophlebiidae (6.90\%) and Caenidae (0.02\%). The most abundant genera were Americabaetis (56.54\%) and Lumahyphes (29.06\%), and the least abundant were Caenis (0.02\%), Nanomis (0.02\%) and Cloeodes (0.04\%) (Table 2). The sampling stations with the highest number of nymphs were 14 and 15, with Americabaetis and Lumahyphes being the most important genera; while the sampling stations with lower abundance were 1, 2 and 13 (with 6, 19 and 26 organisms, respectively). On the other hand, any nymph was recorded at sampling stations 6, 7, 8, 9, 11 and 12 (Table 3). 
Diversity of Ephemeroptera: Stations 14 and 15 located in the lower zone, with higher flow and inside an agricultural area, present the greatest richness (OD) with 5 and 6 taxa, respectively. Shannon diversity (1D) displayed that stations 1, 3, 4, 5 and 15 were the most diverse, with values between 2.74 to 1.9 effective number of genera; station 1 is located in the confluence area of two streams in the upper part of the river, while stations 3,4 and 5 are in the upper urban area and station 15 is in the area with greatest richness. While sampling stations 2, 10, 13 and 14 recorded the lowest values of 1D (1.0 to 1.31 effective number of genera). It is interesting to note that sampling stations 1, 3, 4 and 15 presented twice as much diversity (1D) as the others, except the 5 . Simpson's dominance (2D) showed a tendency similar to $1 \mathrm{D}$, with few dominant taxa in the different sampling stations; however, in the 15 the dominance of few genera in the assembly was observed (2.02 effective number of genera) (Fig. 2).

Physical, chemical and bacteriological variables: In general, the physical, chemical and bacteriological variables in Ocoa river presented differences in the coefficient of variation. The $\mathrm{pH}$ and temperature showed little variation along the river ( 0.07 and 0.15 , respectively). Others variables exhibited very high standard deviations and coefficients of variation (nitrates, nitrites, ammonium, orthophosphates, total coliforms, $\mathrm{BOD}_{5}, \mathrm{COD}$, surfactants and zinc) (Table 4).

Table 2. Composition of the Ephemeroptera fauna in the 0coa river, during a period of low precipitation.

\begin{tabular}{llc}
\hline \multicolumn{1}{c}{ Family } & \multicolumn{1}{c}{ Genera / Species } & Relative abundance (\%) \\
\hline Baetidae (61.94\%) & Americabaetis alphus & 56.56 \\
& Camelobaetidius edmundsi & 4.74 \\
& Cloeodes & 0.04 \\
& Nanomis galera & 0.02 \\
& Zelusia & 0.41 \\
& Varipes & 0.17 \\
\hline Caenidae (0.02\%) & Caenis & 0.02 \\
\hline Leptohyphidae (31.13\%) & Lumahyphes & 29.07 \\
& Tricorythodes & 2.06 \\
\hline Leptophlebiidae (6.90\%) & Thraulodes & 6.9 \\
\hline
\end{tabular}
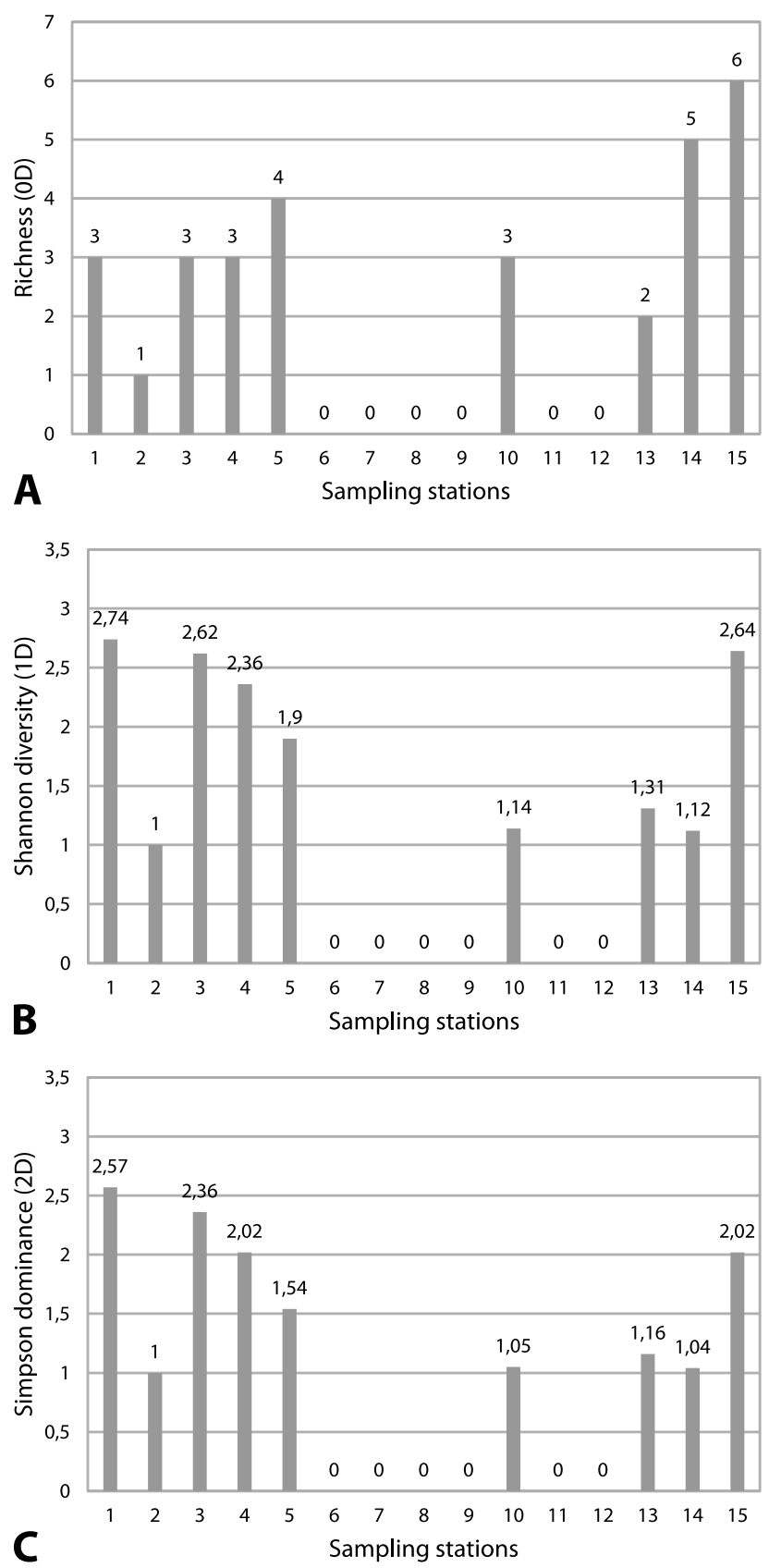

Figure 2. Diversity of the Ephemeroptera assemblage at sampling stations in the 0 coa river. (A) Richness (OD, number of taxa); (B) Shannon diversity (1D, Hill numbers unit); C. Simpson dominance (2D, Hill numbers unit).

Table 3. Distribution of Ephemeroptera abundance in the sampling stations of the 0 coa river.

\begin{tabular}{|c|c|c|c|c|c|c|c|c|c|c|c|c|c|c|c|}
\hline \multirow{2}{*}{ Species } & \multicolumn{15}{|c|}{ Sampling stations } \\
\hline & 1 & 2 & 3 & 4 & 5 & 6 & 7 & 8 & 9 & 10 & 11 & 12 & 13 & 14 & 15 \\
\hline A. alphus & 0 & 0 & 37 & 43 & 1 & 0 & 0 & 0 & 0 & 148 & 0 & 0 & 24 & 2370 & 393 \\
\hline C. edmundsi & 0 & 0 & 70 & 16 & 162 & 0 & 0 & 0 & 0 & 0 & 0 & 0 & 0 & 0 & 5 \\
\hline Cloeodes & 2 & 0 & 0 & 0 & 0 & 0 & 0 & 0 & 0 & 0 & 0 & 0 & 0 & 0 & 0 \\
\hline N. galera & 1 & 0 & 0 & 0 & 0 & 0 & 0 & 0 & 0 & 0 & 0 & 0 & 0 & 0 & 0 \\
\hline Varipes & 0 & 0 & 0 & 0 & 8 & 0 & 0 & 0 & 0 & 0 & 0 & 0 & 0 & 1 & 0 \\
\hline Zelusia & 3 & 19 & 0 & 0 & 0 & 0 & 0 & 0 & 0 & 0 & 0 & 0 & 0 & 0 & 0 \\
\hline Lumahyphes & 0 & 0 & 0 & 0 & 0 & 0 & 0 & 0 & 0 & 1 & 0 & 0 & 0 & 2 & 1547 \\
\hline Tricorythodes & 0 & 0 & 0 & 0 & 0 & 0 & 0 & 0 & 0 & 0 & 0 & 0 & 0 & 2 & 108 \\
\hline Thraulodes & 0 & 0 & 18 & 7 & 35 & 0 & 0 & 0 & 0 & 3 & 0 & 0 & 2 & 52 & 251 \\
\hline Caenis & 0 & 0 & 0 & 0 & 0 & 0 & 0 & 0 & 0 & 0 & 0 & 0 & 0 & 0 & 1 \\
\hline Total & 6 & 19 & 125 & 66 & 206 & 0 & 0 & 0 & 0 & 152 & 0 & 0 & 26 & 2427 & 2305 \\
\hline
\end{tabular}


Table 4. Measures of central tendency of the physical, chemical and bacteriological variables.

\begin{tabular}{|c|c|c|}
\hline Variable & Arithmetic average & Coefficient of variation \\
\hline Temperature $\left({ }^{\circ} \mathrm{C}\right)$ & 26.33 & 0.07 \\
\hline Dissolved oxygen (mg/L) & 3.84 & 3.14 \\
\hline pH (unidades de pH) & 6.84 & 0.15 \\
\hline Electric conductivity (uS/cm) & 252.22 & 0.61 \\
\hline Total dissolved solids (ppm STD) & 111.40 & 0.53 \\
\hline Turbidity (UNT) & 17.78 & 0.70 \\
\hline Bicarbonates $\left(\mathrm{mg} / \mathrm{L} \mathrm{CaCO}_{3}\right)$ & 61.07 & 0.77 \\
\hline Nitrates $\left(\mathrm{mg} / \mathrm{L} \mathrm{NO}_{3}^{-}\right)$ & 0.68 & 1.70 \\
\hline Nitrites (mg/L NO${ }_{2}^{-}$) & 0.08 & 1.61 \\
\hline Ammonium (mg/L NH${ }_{4}^{+}$) & 4.48 & 1.67 \\
\hline Orthophosphates (mg/L PO ${ }_{4}^{3-}$ ) & 8.09 & 2.92 \\
\hline Sulfates $\left(\mathrm{mg} / \mathrm{LSO}_{4}{ }^{2-}\right)$ & 20.94 & 0.56 \\
\hline Total coliforms (NMP/100 ml) & 11124502.67 & 2.09 \\
\hline $\mathrm{DBO}_{5-20{ }^{\circ} \mathrm{C}}\left(\mathrm{mg} / \mathrm{L} \mathrm{O}_{2}\right)$ & 25.47 & 1.67 \\
\hline $\mathrm{DQO}\left(\mathrm{mg} / \mathrm{L} \mathrm{O}_{2}\right)$ & 63.53 & 1.08 \\
\hline Anionic surfactants (mg/L) & 1.20 & 1.64 \\
\hline $\operatorname{Zinc}(\mathrm{mg} / \mathrm{L} \mathrm{Zn})$ & 0.17 & 1.75 \\
\hline Iron (mg/L Fe) & 1.50 & 0.42 \\
\hline Flow $\left(\mathrm{m}^{3} / \mathrm{s}\right)$ & 2.68 & 0.47 \\
\hline
\end{tabular}

The ICOMO's lowest values were presented in sampling stations 1 and $2(<0.2)$, which reflected an "optimal" water quality. Sampling station 3 was located in the urban area and presented a value close to 0.5 , which indicates that the quality of the water is in a "doubtful" category. From sampling station 4 to 11 , with the exception of 10 , the values were higher than 0.8 , which represents a high degree of contamination. However, that trend changes in the last sampling stations (12, 13, 14 and 15), where the values of the index gradually decrease from an "awful" to a "dubious" water quality (ICOMO from 0.9 to 0.6 ) (Fig. 3). It is important to note that the highest values were recorded in sampling stations 5, 8 and 11, which correspond to the three tributaries evaluated (Caño Buque, Caño La Cuerera and Caño Maizaro, respectively). A different behavior was registered in sampling station 10 which presented a low index value $($ ICOMO $=0.54$, "doubtful" category) in comparison to the neighboring sampling stations.

Besides, in contrast to the diversity measures, the sampling stations $(6,7,8,9,11$ and 12) with pollution high (ICOMO $=0.9$ to 1.0 ) the richness and diversity (OD, 1D and 2D) was zero (except the sampling stations 4 and 5). Sampling stations 1, 2, 3, 13, 14 and 15 registered high richness and diversity while the ICOMO was decreasing.

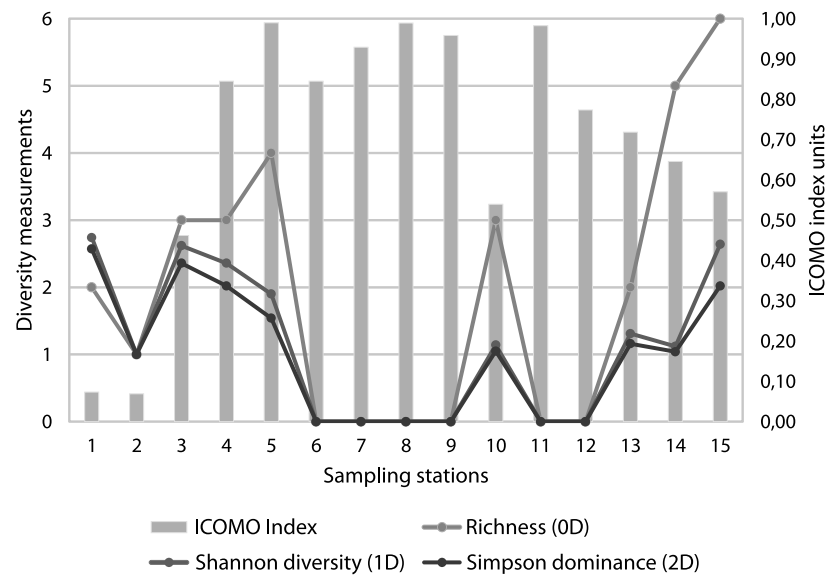

Figure 3. Trends in the spatial variation of the diversity measures: Richness (0D), Shannon diversity (1D) and Simpson dominance (2D) in the primary axis and the ICOMO index in the axis secondary. Aquatic quality values: Optimum (0-0.2); Good (0.2-0.4); Doubtful (0.4-0.6); Inadequate (0.6-0.8); Awful (0.8-1).

The GLM for Ephemeroptera's richness resulted in six models from lowest (best) AIC value. Coliform totals, ICOMO, nitrates, nitrites and temperature were significative variables in the models. The model six (6) had the best goodness of fit $(R 2=0,91)$; ICOMO and nitrates were the signiticative predictor variables with possitive effect in the model for the richness (OD) (Table 5).

Relationship between the physical chemical and bacteriological variables with the Ephemeroptera: The RDA model explained $47.19 \%$ of the variation in the stream in relation to $\mathrm{pH}$, nitrites and flow, in a significant relationship between response and explanatory variables $\left(P<0.012, R^{2}\right.$ Adjusted $\left.=49.5 \%\right)$. The first two axes

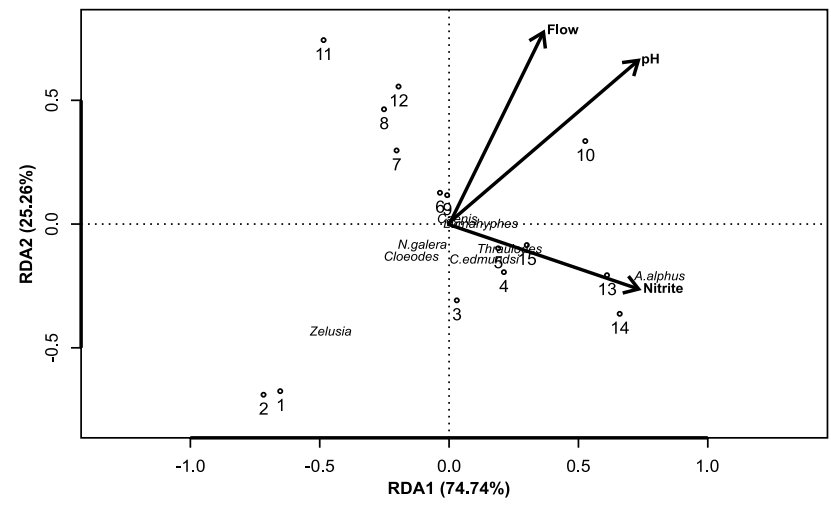

Figure 4. RDA classification diagram of the Ephemeroptera assemblage with respect to physical, chemical and bacteriological variables and sampling stations.

Table 5. Generalized linear model (GLM) for Ephemeroptera's richness (OD). Effects of each predictor on richness (OD). Variables not selected for the model are shown as (-). $N=15$ for the models. Significant values $(p<0.05$, test $=$ Chi square $)$ are in bold face.

\begin{tabular}{|c|c|c|c|c|c|c|c|c|c|c|}
\hline Model & (Intercept) & Caud & Col.Tot & ICOMO & Nitra & Nitri & OD & Temp & AIC & $R^{2}$ \\
\hline 1 & -16.999 & -2.172 & - & - & - & 11.052 & - & 0.811 & 50.254 & 0.6743 \\
\hline 2 & 0.979 & - & 0.000000032 & -2.185 & 0.590 & - & - & - & 51.649 & 0.6353 \\
\hline 3 & -1.101 & - & 0.000000031 & - & 0.546 & - & 0.015 & - & 51.672 & 0.6347 \\
\hline 4 & -1.983 & - & 0.000000042 & - & 0.417 & 4.132 & 0.021 & - & 51.762 & 0.7626 \\
\hline 5 & -4.841 & -2.877 & - & 10.643 & 0.390 & 17.384 & 0.062 & - & 52.218 & 0.9130 \\
\hline 6 & -18.448 & -2.304 & 0.000 & - & 一 & 12.352 & - & 0.864 & 52.885 & 0.7312 \\
\hline
\end{tabular}


of the RDA explained $51.5 \%$ of this variation and the first axis explained $38.3 \%$ of this variation (eigenvalue $=0.18$ ). It was possible to visualize that Americabaetis, Thraulodes and Camelobaetidius were positively related with Nitrite and the sampling stations 5, 13, 14 and 15, and negatively with the sampling stations $7,8,11$ and 12 . The second axis explained $13.19 \%$ of variation (eigenvalue $=0.062$ ) and Zelusia, Cloeodes and Nanomis, in the sampling stations 1 and 2, were associated negatively to flow and $\mathrm{pH}$, and the sampling station 10 . The remaining genera represented by the cloud of points near the origin (point 0,0 ) apparently do not indicate any relationship with any sampling station or variable (Fig. 4).

\section{DISCUSSION}

Taxonomic composition of the Ephemeroptera assembly: There are nine Ephemeroptera families reported for Colombia (Salles et al., 2020), four were recorded in this study: Baetidae, Leptohyphidae, Leptophlebiidae and Caenidae. These correspond to $44.4 \%$ of registered families in the country and they have the largest number of genera and species recorded (Dias et al., 2009; Forero-Céspedes et al., 2014; García et al., 2013; Gutiérrez \& Reinoso-Flórez, 2010; Gutiérrez et al., 2013; Gutiérrez \& Llano, 2015; Hoyos et al., 2014; Molineri, 2014; Molineri et al., 2011; Motta-Díaz et al., 2012; Rozo \& Salinas, 2016; Salinas et al., 2011, 2012, 2013; Salinas-Jiménez et al., 2017, 2018; Vinasco-Mondragón \& Zúñiga, 2016; Zúñiga et al., 2014, 2015; Zúñiga \& Torres-Zambrano, 2015). Baetidae and Leptohyphidae were the most abundant and frequent in the different sampling stations, similar to what was found by Zamora (2015) in Orinoquia piedmont streams, where he further reported Leptophlebiidae and Oligoneuriidae. Likewise, studies conducted at east of the Meta (Franco et al., 2012) and Casanare department (Camacho-Reyes \& Camacho-Rozo, 2010) have been registered these families along with Caenidae, in savanna rivers and esteros. However, it can exist difference in the taxonomic composition (genera and species) due to the local biological, physical, chemical, hydrological and geomorphological attributes of these ecosystems compared to a piedmont river as the Ocoa (Donato \& Galvis, 2008).

In this work three new registers of genera are reported for the Meta department: Cloeodes, Lumahyphes and Zelusia. Until now, 18 genera and 11 species were reported for this department (Dias et al., 2009; SalinasJiménez et al., 2017, 2018, 2019; Zamora, 2015; Zúñiga \& Torres-Zambrano, 2015). With this research the genera registered increases to 21 , which correspond to $38 \%$ of the approximately 55 genera recorded in Colombia (Dias et al., 2009; Forero-Céspedes et al., 2014; García et al., 2013; Gutiérrez \& Reinoso-Flórez, 2010; Gutiérrez et al., 2013; Gutiérrez \& Llano, 2015; Hoyos et al., 2014; Molineri, 2014; Molineri et al., 2011; Motta-Díaz et al., 2012; Rozo \& Salinas, 2016; Salinas et al., 2011, 2012, 2013; SalinasJiménez et al., 2017, 2018, 2019; Zúñiga et al., 2014, 2015;
Zúñiga \& Torres-Zambrano, 2015). In addition, A. alphus is reported for the first time for this region, increasing the number of species to 12 .

The variation in composition of mayflies at sampling stations was characterized by the abundance of $A$. alphus and Lumahyphes. The first was found in seven sampling stations $(3,4,5,10,13,14,15)$; and second was reported in three sampling stations $(10,14,15)$. This situation could be explained by particularity in their lifecycles; for example, the coincidence of sampling date with a pre-emergence period of nymphs (Domínguez et al., 2009; Brittain, 1982), particularly at the sampling stations 14 (A. alphus) and 15 (Lumahyphes). Other reason may be that the supply nutrients decreased in these stations and this could favor them (Roldán \& Ramírez, 2008); the above can be contrasted with ICOMO, in effect it was low to sampling station 3, 14 and 15, while it was increasing at sampling station 4 to 13 .

Nanomis, Zelusia and Cloeodes registered the lowest abundance and frequency in the sampling stations before the urban center (1 and 2). They are not very tolerant organisms of pollution and environmental disturbance (Buss \& Salles, 2007; Chacón \& Segnini, 2007), and they have particular characteristics of distribution (Domínguez et al., 2009). The register of Caenis at sampling station 15 is associated with the preference of these nymphs to live in slow to moderate currents with sediment areas, as well as lakes and floodplains (Domínguez et al., 2009; Flowers \& De La Rosa, 2010; Menetrey et al., 2008; Zúñiga et al., 1997). However, it has also been reported that Ephemeroptera nymphs are part of the drift of the rivers, as a defensive behavior, dispersion, feeding activities, contamination or unfavorable changes in the water quality and their habitat (Brittain \& Eikeland, 1988; Elliott, 1967; Flowers \& De La Rosa, 2010).

Diversity of the Ephemeroptera assembly: The lotic ecosystems provide a multiplicity of suitable microhabitats for the establishment of macroinvertebrates (Beisel et al., 1998). They are susceptible to loss the structure and function of their natural characteristics due to the effects of pollution, especially in urban rivers (Bauernfeind \& Moog, 2000; Prat et al., 2009; Ramírez \& Viña, 1998). The richness (OD), diversity of Shannon (1D) and dominance (2D) of Ephemeroptera recorded in this study were affected by urbanization (predominant land use matrix along the river). In urbanized zones the diversity was low and in six stations there were none nymph (sampling stations 6 , 7, 8, 9, 11 and 12), including tributaries (Caño La Cuerera and Caño Maizaro). This is because the Ocoa river is the main sink for discharges of Villavicencio city; along with its tributaries Caño Grande, Buque, Maizaro, La Cuerera, Pendejo, Tigre, Arenoso and Siete vueltas, with more than 100 discharges identified, in approximately $17 \mathrm{~km}$ of distance, which greatly affects the functioning of the ecosystem (Osorio-Ramírez et al., 2015). It has been reported in rivers of other regions, where the main factor influencing the richness and diversity of aquatic insects is the urbanization, along with domestic and industrial wastewater, deforestation, erosion processes, sediment 
drag, groundwater contamination, among others, that cause negative effects by partially or completely transforming the natural characteristics of aquatic ecosystems (Bauernfeind \& Moog, 2000; Bispo \& Oliveira, 2007; Moore \& Palmer, 2005; Roldán \& Ramírez, 2008).

On the other hand, the highest values of diversity were recorded in the highest stations (1, 2, 3 and 4) and in the lowest (14 and 15). The first ones still do not present a high degree of contamination and the last ones are favored by the recovery and dilution by healthy tributaries, which allows the establishment of mayflies' nymphs. Additionally, the matrix of land use in such stations corresponds to agriculture and livestock, which could favor the diversity and richness of these insects, as occurs in sampling stations 1, 3 and 15. In other studies it has been found that the diversity of aquatic insects in sites with agricultural influence is greater with respect to urbanized sites (Moore \& Palmer, 2005; Cortezzi et al., 2009).

Physical, chemical and bacteriological variables: In general, most variables showed high variation ( $C V>1.0)$, possibly due to the heterogeneity of anthropogenic activities that develop along the river; for example, water catchments for domestic use and impacts by tourism are characteristic of the upper zone; in the middle prevail the domestic discharges on direct tributaries, in addition to discharges by oil industries, animal benefit plants, among others; and finally, in the lower area, the contribution of domestic discharges, the influence of oil activity and catchments for agricultural use (Osorio-Ramírez et al., 2015).

The highest values of dissolved oxygen were registered in the first three sampling stations and decreased significantly on the last (located after the urban area: 14 and 15). This could be related to the impact generated by the contribution of organic matter, which increase the activity of chemical and microbiological processes and allow the establishment of tolerant organisms such as Chironomidae, Oligochaeta and Gastropoda; these organisms can tolerate low oxygen conditions in the water (Jiménez \& Vélez, 2006). This is validated by the high values of total coliforms (from 170,000 to 79 , $900,000 \mathrm{NMP} / 100 \mathrm{ml}$ ) at the stations located in the urban area. Those values infringe the specifications of article 38 of Decree 1594 of 1984 and indirectly influence the behavior of $\mathrm{BOD}_{5}, \mathrm{COD}$ and dissolved oxygen; that situation represents an evident risk factor for the health of people who are related to the use of water resources in these sectors.

Nitrites and nitrates showed low values from sampling station 1 to 10 , but gradually increased towards station 15. This is possibly related to livestock and agricultural crops (such as rice and palm) characteristic of this basin (Osorio-Ramírez et al., 2015). The presence of ammonium is an indicator of contamination associated with chemical processes of degradation of organic matter (Pacheco et al., 2002) and according to Decree 1594 of 1984, the admissible limit for the destination of the resource for the preservation of flora and fauna in freshwater should not exceed $0.1 \mathrm{mg} / \mathrm{L}$. The sampling stations that were found below that value were 1 and 2, while the $4,6,11,12$ and 13 had values higher than $4.5 \mathrm{mg} / \mathrm{L}$; the highest value of ammonium was registered in the tributary Caño Buque, with 30 mg/L, which indicates a potential danger to public health, as well as for the establishment of aquatic communities. Additionally, the flow values showed a gradual increase downstream, however they decreased in the last stations (14 and 15). That situation could be related to water abstraction destined for extensive livestock and agricultural crops such as palms or flow deviations (Osorio-Ramírez et al., 2015), which puts in serious problems the preservation of aquatic life.

Respect to ICOMO, the sampling stations with category of "optimal" water aquatic were 1 and 2; which could be associated with the fact that the anthropic impact associated with them is lower magnitude (Table 1) compared to the urban area's sampling sites. Sampling station 3, the first in the urban area presented the category of "doubtful" water quality because at this point there are accumulated wastewater from the urbanization and industry, oil companies, fish farms, animal benefit plants for chickens, and so on, which could affect the structure and function of the ecosystem (Bauernfeind \& Moog, 2000; Prat et al., 2009). From sampling station 4 to 11, except 10 , the index values rise drastically. This represents a high degree of contamination, but in the last sampling stations $(12,13,14$ and 15$)$ it is observed how the values of the index decrease, when changing from "awful" to "doubtful" water quality. The flow of water and the biotic activities facilitate the processing of the organic matter and therefore the recovery of river (Roldán \& Ramírez, 2008). The low pollution value of sampling station 10 , compared to the surrounding ones, may be due to the dilution effect between 9 and 10 for the Caños Chavicure and Campoalegre (Osorio-Ramírez et al., 2015). Then, better environmental conditions contribute to the dilution of the pollutant load of the main channel (Roldán \& Ramírez, 2008).

The GLM resulted in that coliform totals, ICOMO, nitrates, nitrites and temperature were significative variables predictor in the six models. This is congruent with the behavior observed and discuted about of variation physical, chemical and bacteriological variables with the diversity. The highest stations $(1,2,3,4)$ and lowest $(14,15)$ presented a low contamination's pressure and the best Ephemeroptera's richness. The best model (6) $\left(R^{2}=0.91\right.$, Table 5$)$ had the ICOMO and nitrates like signiticative predictor variables for richness (OD); for that reason it's possible that the decision makers could employ this predictor variables like indicators about the health situation of the Ocoa river.

Relationship between physical, chemical and bacteriological variables with Ephemeroptera: Americabaetis alphus was the most abundant and frequent at Ocoa river, associated mainly with rapids and rocky substrates with high contents of detritus or particulate organic matter. It was presented in stations from "doubtful" to "awful" water 
quality, according to ICOMO (Fig. 4) and it had greater degree of association with nitrites, principally in the stations 13 and 14 (Fig. 3). Unlike found by Buss \& Salles (2007), who mention that this species was found predominantly in litter substrate and in less proportion in rocky substrate. Additionally, nymphs Americabaetis has been reported associated with alkalinity, electrical conductivity, SDT, pH, hardness, flow, temperature, chlorides and phosphates in a urban stream in the Tolima department (Forero-Céspedes \& Reinoso-Flórez, 2013), variables that denote a gradient of contamination by water mineralization (Ramírez et al., 1997; Ramírez \& Viña, 1998).

Camelobaetidius was recorded in fast currents and sampling stations with a degree of aquatic contamination from "doubtful" to "awful" (Fig. 4). Camelobaetidius is a detritivore genus, scraper of plant material from rocky surfaces and aquatic plants, with morphological adaptations such as setae in the cerci that help it to swim and spatulate claws to scrape and grapple to the substrate. They are considered to be not very sensitive to being found in clean and contaminated waters (Buss \& Salles, 2007; Rojas et al., 1993). Likewise, Forero-Céspedes \& Reinoso-Flórez (2013) found this genus associated with variables that indicate contamination by water mineralization, such as alkalinity, hardness, electrical conductivity, SDT, pH, flow rate, temperature, chlorides and phosphates.

Varipes was found in rapids and rocky substrates, in waters from "inadequate" to "awful" quality (Fig. 4). Therefore, it could be inferred that this genus is tolerant to the contamination condition. Castillo \& Pérez (2011) found it associated to gravel and sand substrates, and some degree of tolerance to habitat disturbance due to human activities, given the characteristics of the places where it was recorded. Additionally, Reynaga \& Dos Santos (2012) found that this genus had characteristics such as moderate body hardness, oval-shaped gills, elongated body, claws to face the flow and high tolerance to oxygen deficit.

Nanomis, Zelusia, and Cloeodes were found in rapids and rocky substrates, "optimum" water quality (Fig. 4) and associated with high oxygen conditions, on the sampling stations of the high zone ( 1 and 2, with dissolved oxygen values of 7.96 and $8.19 \mathrm{mg} \mathrm{O}_{2} / \mathrm{L}$ respectively); this would allow to suppose that these taxa are sensitive to conditions of water contamination. As reported by Buss \& Salles (2007), Zelusia is a genus with very sensitive organisms, good swimmers of fast and slow currents. Chacón \& Segnini (2007) reported that Nanomis is little tolerant to contamination, and associated with very low levels of water mineralization (expressed by the variables conductivity, hardness and alkalinity). Cloeodes organisms have a hydrodynamic body, which helps them resist the current and inhabit the stones (Buss \& Salles, 2007). Forero-Céspedes \& Reinoso-Flórez (2013) found it associated with variables related to mineralization processes: alkalinity, hardness, electrical conductivity, SDT, pH, flow, temperature, chlorides and phosphates. In general, Cloeodes is a sensitive genus to contamination condition; however, this qualifier may change with respect to the species (Buss \& Salles, 2007).

Lumahyphes was found in slow currents and rocky substrates with sand; it was the second most abundant genus (with greater importance in station 15), related to stations with "doubtful" and "inadequate" water quality (Fig. 4), with some degree of tolerance to contamination conditions. Any information was found associated with ecological aspects of Lumahyphes, most of the information corresponds to taxonomic reports and species distribution (Boldrini et al., 2015; Molineri, 2010; Molineri \& Zúñiga, 2004); so this study is one of the first to provide information on ecological aspects of the genus.

The genus Tricorythodes was found in slow and rapid streams of rocky substrates with sandy bottoms. It showed association with stations of "uncertain" or "inadequate" water quality (Fig. 4). These results coincide with that reported by Rojas et al. (1993) who point out that it lives from warm to cold currents, their body have setae abundant, with filtering habits and they inhabit sandbanks at water bottom. In addition, they can be found from clean to slightly contaminated waters (Zúñiga et al., 1997), and exhibit a greater degree of tolerance to high values of conductivity and hardness (Chacón \& Segnini, 2007).

Thraulodes was one of the most frequent genus in the sampling stations, in fast currents with rocky substrates, with conditions from "doubtful" to "awful" water quality (Fig. 4) and associated with nitrates (Fig. 3). Zúñiga et al. (1997) indicated that these nymphs can be found in clean to slightly polluted waters, as reported by Chacón \& Segnini (2007) that consider Thraulodes as a slightly tolerant, associated with low mineralization of water and sensitive to contamination by organic matter and oxygen deficiency.

Otherwise, the genus Caenis presented a single individual in station 15 , in a microhabitat of slow current and rocky substrate, and associated with nitrates in "doubtful" water quality (Fig. 4). Zúñiga et al. (1997) signalized that the organisms of this genus are typical of waters with little or any current, associated with areas of mud, vegetation or muddy banks at water bottom and that rarely inhabit the middle or superficial part of the water column. It is known that Caenis can tolerate high polluted and eutrophic waters with high temperatures and low oxygen levels (Flowers \& De La Rosa, 2010).

\section{CONCLUSIONS}

This study highlights the effect of water pollution on the Ephemeroptera diversity in a low precipitation period. The direct and diffuse domestic and industrial waste discharges that the Ocoa river collects along, as well as tributaries with the same nature, showed that most stations located in the urban area of Villavicencio did not register mayflies. The stations at the ends of the city increased abundance and their diversity. We found that the residual load discharged into this river represents a public health problem, also an ecological degradation 
that limits the availability and diversity of habitats for the establishment of Ephemeroptera nymph. Most water pollution problems are generated as a result of the development of human activities, so it is important that they begin to generate strategies from the field of environmental management to minimize the impact on water resources.

\section{ACKNOWLEDGMENTS}

We want to express our thanks to Instituto de Ciencias Ambientales de la Orinoquia Colombiana (ICAOC). Likewise, to Universidad de los Llanos and Ecopetrol S.A. for the logistical and administrative support in the collaboration framework agreement "Identification of alternatives for environmental management of the Guayuriba and Ocoa rivers, and Caño Quenane-Quenanito of the upper Meta river basin, based in educational, investigative and social projection strategies", number 5211592. To the researchers of the Instituto de Biodiversidad Neotropical of CONICET, Argentina: Eduardo Domínguez, Carlos Molineri, Carolina Nieto and Daniel Dos Santos for their advice with Ephemeroptera fauna. Nataly Urrea for her collaboration with the translation of the manuscript and Oscar Diaz Celis for his contribution in preparing the study map. Finally, to the reviewers who helpfully improved this manuscript.

\section{AUTHORS' CONTRIBUTIONS}

Formulation research question: J.I.R.P., D.P.O.R., J.M.V.R.; Taxonomic determination: J.I.R.P., L.G.S.J.; Data analysis: J.I.R.P., J.M.V.R.; Supervision: D.P.O.R., J.M.V.R.; Writing-original draft: J.I.R.P.; Funding acquisition, experimental design and project administration: D.P.O.R., C.I.C.C. All authors read, writing-review, editing and approved the final document.

\section{REFERENCES}

Arimoro, F.0.\& Muller, W.J. 2010. Mayfly (Insecta: Ephemeroptera) community structure as an indicator of the ecological status of a stream in the Niger Delta area of Nigeria. Environmental Monitoring and Assessment, 166(1-4): 581-594.

Barber-James, H.M.; Gattolliat, J.L.; Sartori, M. \& Hubbard, M.D. 2008. Global diversity of mayflies (Ephemeroptera, Insecta) in freshwater. Hydrobiology, 595: 339-350.

Bartoń, K. 2020. MuMIn: Multi-Model Inference. R package version 1.43.17. https://CRAN.R-project.org/package=MuMln.

Bauernfeind, E. \& Moog, 0. 2000. Mayflies (Insecta: Ephemeroptera) and the assessment of ecological integrity: a methodological approach. Hydrobiology, 422-423: 71-83.

Beisel, J.N.; Usseglio-Polatera, P.; Thomas, S. \& Moreteau, J.C. 1998. Stream community structure in relation to spatial variation: the influence of mesohabitat characteristics. Hydrobiology, 389(1-3): 73-88.

Bispo, P.C. \& Oliveira, L.G. 2007. Diversity and structure of Ephemeroptera, Plecoptera and Trichoptera (Insecta) assemblages from riffles in mountain streams of Central Brazil. Brazilian Journal of Zoology, 24(2): 283-293.

Blanchet, F.G.; Legendre, P. \& Borcard, D. 2008. Forward selection of explanatory variables. Ecology, 89(9): 2623-2632.

Blann, K.L.; Anderson, J.L.; Sands, G.R. \& Vondracek, B. 2009. Effects of agricultural drainage on aquatic ecosystems: a review. Critical reviews in environmental science and technology, 39(11): 909-1001.

Boldrini, R.; Santos, G.C. \& Oliveira, D.R. 2015. First record of the genus Lumahyphes Molineri, 2004 (Ephemeroptera: Leptohyphidae) from Brazil with description of a new species. Zootaxa, 4013: 143-146.

Brittain, J.E. 1982. Biology of mayflies. Annual Review of Entomology, 27: 119-147.

Brittain, J.E. \& Eikeland, T.J. 1988. Invertebrate drift - A review. Hydrobiology, 166: 77-93.

Buss, D.F. \& Salles, F.F. 2007. Using Baetidae as biological indicators of environmental degradation in a Brazilian river basin. Environmental Monitoring and Assessment, 130: 365-372.

Camacho-Reyes, J.A. \& Camacho-Rozo, C.P. 2010. Aspectos sobre la historia natural de macroinvertebrados en esteros semipermanentes de la altillanura en el departamento de Casanare. Revista Orinoquia, 14:71-82.

Castillo, M.M. \& Pérez, B. 2011. Varipes (Ephemeroptera: Baetidae) en Venezuela: descripción de nueva especie. Revista Colombiana de Entomología, 37(2): 346-349.

Chacón, M.M. \& Segnini, S. 2007. Óptimos y tolerancias ambientales para las ninfas de Ephemeroptera en un gradiente atititudinal en la cordillera de Mérida, Venezuela. Entomología Mexicana, 6: 225-230.

Correa, G. 2014. Concentración regional de la población por niveles de riqueza hídrica en Colombia. Revista CIFE, 16: 153-165.

Cortezzi, S.S.; Bispo, P.C.; Paciencia, G.P. \& Leite, R.C. 2009. Influência da ação antrópica sobre a fauna de macroinvertebrados aquáticos em riachos de uma região de cerrado do sudoeste do Estado de São Paulo. Iheringia, Série Zoologia, 99(1): 36-43.

Crawley, M.J. 2007. The R Book. Chichester, Wiley. 945p.

Decreto 1594 de 1984. Por el cual se reglamenta parcialmente el Título I de la Ley 09 de 1979, así como el Capítulo II del Título VI - Parte III - Libro II y el Título III de la Parte III Libro I del Decreto 2811 de 1974 en cuanto a usos del agua y residuos líquidos. Colombia, Ministro de Agricultura. Diario Oficial 36700 de julio 23 de 1984.

Dias, L.G.; Zuñiga, M. Del C. \& Bacca, T. 2009. Estado actual del conocimiento del orden Ephemeroptera en Colombia. In: Congreso de la Sociedad Colombiana de Entomología, 26ํ. Memorias. Cali, Sociedad Colombiana de Entomología. p. 236-253.

Domínguez, E.; Molineri, C. \& Nieto, C. 2009. Ephemeroptera.In:Domínguez, E. \& Fernández, H.R. (Eds.). Macroinvertebrados bentónicos sudamericanos. Sistemática y biología. Tucumán, Fundación Miguel Lillo. p. 55-93

Domínguez, E.; Molineri, C.; Pescador, M.L.; Hubbard, M.D. \& Nieto, C. 2006. Ephemeroptera of South America. Aquatic Biodiversity in Latin America. 2. ed. Sofia, Pensoft.

Dominique, Y.; Mathuriau, C. \& Thomas, A. 2001. Etude systématique du genre Camelobaetidius Demoulin, 1966 en Colombie (Ephemeroptera: Baetidae). Bulletin de la Société d' Histoire Naturelle de Toulouse, 137: 17-32.

Donato, J.C. \& Galvis, G. 2008. Tipología de los ríos colombianos. In: Donato, J. (Ed.). Ecología de un río de montaña de los Andes Colombianos (río Tota, Boyacá). Bogotá, Universidad Nacional de Colombia.

Dormann, C.F.; Elith, J.; Bacher, S.; Buchmann, C.; Carl, G.; Carré, G.; Marquéz, J.R.G.; Gruber, B.; Lafourcade, B.; Leitão, P.J.; Münkemüller, T.; Mcclean, C.; Osborne, P.E.; Reineking, B.; Schröder, B.; Skidmore, A.K.; Zurell, D. \& Lautenbach, S. 2013. Collinearity: a review of methods to deal with it and a simulation study evaluating their performance. Ecography, 36: 27-46. 
Dos Reis Oliveira, P.C.; Kraak, M.H.S.; Pena-Ortiz, M.; van der Geest, H.G. \& Verdonschot, P.F.M. 2020. Responses of macroinvertebrate communities to land use specific sediment food and habitat characteristics in lowland streams. Science of the total environment, 703(13506): 1-9.

Dray, S.; Bauman, D.; Blanchet, G.; Borcard, D.; Clappe, S.; Guenard, G.; Jombart, T.; Larocque, G.; Legendre, P.; Madi, N. \& Wagner, H.H. 2019. adespatial: Multivariate Multiscale Spatial Analysis. R package version 0.3-7. https:// CRAN.R-project.org/package $=$ adespatial.

Dunn, P.K. \& Smyth, G.K. 2018. Generalized linear models with examples in $R$. New York, Springer Science+Business Media.

Edsall, T. 2001. Burrowing mayflies (Hexagenia) as indicators of ecosystem health. Aquatic Ecosystem Health \& Management, 4(3): 283-292.

Elliott, J.M. 1967. The life histories and drifting of the Plecoptera and Ephemeroptera in a Dartmoor Stream. Journal of Animal Ecology, 36(2): 343-362.

Flowers, R.W. \& De La Rosa, C. 2010. Ephemeroptera. Revista de Biología Tropical, 58(Suppl. 4): 63-93.

Forero-Céspedes, A.M. \& Reinoso-Flórez, G. 2013. Estudio de la familia Baetidae (Ephemeroptera: Insecta) en una cuenca con influencia de la urbanización y agricultura: río Alvarado - Tolima. Revista de La Asociación Colombiana de Ciencias Biológicas, 25: 12-21.

Forero-Céspedes, A.; Gutiérrez, C. \& Reinoso-Flórez, G. 2014. Nuevos registros de Baetidae (Ephemeroptera: Insecta) para Colombia y el departamento del Tolima. Revista de La Asociación Colombiana de Ciencias Biológicas, 26: 59-67.

Franco, Á.; González, J.D.; Montaño, S.; Ulloa, L.; Martelo, N.; Martínez, D.; Morales, D.; Romero, N.; Francisca, L.; David, D.; Luque, F. \& Ruíz, D. 2012. Estudio regional de los ecosistemas acuáticos y terrestres de la Región de Carimagua, Llanos Orientales, Meta, Colombia. Documento de trabajo (No publicado), Bogotá: Universidad Nacional de Colombia.

García, E.P. 2020. Notes for Predictive Modeling. Avalaible: https://bookdown. org/egarpor/PM-UC3M. Access: 31/05/2020.

García, L.F.; Hoyos, D.C. \& Días, L. 2013. The first record of Choroterpes (Ephemeroptera: Leptophlebiidae) para Caldas, Colombia. Revista Colombiana de Entomología, 39: 164-165.

Gutiérrez, C. \& Reinoso-Flórez, G. 2010. Géneros de ninfas del orden Ephemeroptera (Insecta) del departamento del Tolima, Colombia: listado preliminar. Biota Colombiana, 11: 23-32.

Gutiérrez, Y. \& Llano, C. 2015. First record of Americabaetis alphus (Insecta: Ephemeroptera: Baetidae) from Colombia. Revista Colombiana de Entomología, 41(1): 147-148.

Gutiérrez, Y.; Dias, L.G. \& Salles, F.F. 2013. Paracloeodes caldensis (Ephemeroptera: Baetidae), an atypical new species from the Colombian Andes. Zootaxa, 3721: 291-295.

Hammer, Ø.; Harper, D.A.T. \& Ryan, P.D. 2009. PAST - Palaeontological Statistics. Oslo: University of Oslo.

Hill, M.O. 1973. Diversity and evenness: a unifying notation and its consequences. Ecology, 54: 427-432.

Hodkinson, I.D. \& Jackson, J.K. 2005. Terrestrial and aquatic invertebrates as bioindicators for environmental monitoring, with particular reference to mountain ecosystems. Environmental Management, 35(5): 649-666.

Hoyos, D.C.; García, L.F.; Rivera, F.; López, G.; Zúñiga, M. Del C. \& Dias, L.G. 2014. Contribución al conocimiento de las especies de Haplohyphes Allen (Insecta: Ephemeroptera: Leptohyphidae) en Colombia. Caldasia, 36(1): 125-138.

Hubbard, M.D. \& Peters, W.L. 1978. Environmental requirements and pollution tolerance of Ephemeroptera. Cincinnati, U.S. Environmental Protection Agency (EPA-60078-061).

Jiménez, M.A. \& Vélez, M.V. 2006. Análisis comparativo de indicadores de la calidad de agua superficial. Avances en Recursos Hidráulicos, 14: 53-70.
Jost, L. 2006. Entropy and diversity. Oikos, 113(2): 363-375.

Lugo-Ortiz, C.R. \& Mccafferty, W.P. 1996. Taxonomy of the Neotropical genus Americabaetis, new status (Insecta: Ephemeroptera: Baetidae). Studies on Neotropical Fauna and Environment, 31(3-4): 156-169.

Lugo-Ortiz, C.R. \& Mccafferty, W.P. 1999. Three new genera of small minnow mayflies (Insecta: Ephemeroptera) from the Andes and Patagonia. Studies on Neotropical Fauna and Environment, 34(2): 88-104.

Mallin, M.A. \& Cahoon, L.B. 2003. Industrialized animal production - a major source of nutrient and microbial pollution to aquatic ecosystems. Population and Environment, 24(5): 369-385.

Menetrey, N.; Oertli, B.; Sartori, M.; Wagner, A. \& Lachavanne, J.B. 2008. Eutrophication: Are mayflies (Ephemeroptera) good bioindicators for ponds? Hydrobiologia, 597: 125-135.

Miranda, A. 1987. Utilización de macroinvertebrados bénticos como indicadores biológicos de la calidad del agua en el río Viao-Piloña (Asturias). Limnética, 3: 141-150.

Molineri, C. 2010. Las especies de Leptohyphidae (Ephemeroptera) de las yungas de Argentina y Bolivia: diagnosis, distribución y claves. Revista de La Sociedad Entomológica Argentina, 69(3-4): 233-252.

Molineri, C. 2014. Description of Alloretochus sigillatus new species with comments and new distributional records for Alloretochus peruanicus (Ephemeroptera, Caenidae, Brachycercinae). Zootaxa, 3821: 139-145.

Molineri, C \& Zúñiga, M. Del C. 2004. Lumahyphes, a new genus of Leptohyphidae (Ephemeroptera). Aquatic Insects, 26(1): 19-30.

Molineri, C.; Cruz, P.V. \& Emmerich, D. 2011. A new species of Asthenopus (Ephemeroptera: Polymitarcyidae: Asthenopodinae) from Brazil and Colombia. Zootaxa, 2750: 33-38.

Moog, 0.; Bauernfeind, E. \& Weichselbaumer, P. 1997. The use of Ephemeroptera as saprobic indicators in Austria. In: Landolt, P. \& Sartori, M. (Eds.). Ephemeroptera y Plecoptera: biology-ecology-systematics. Fribourg, MTL. p. 254-260.

Moore, A.A. \& Palmer, M.A. 2005. Invertebrate biodiversity in agricultural and urban headwater streams: implications for conservation and management. Ecological Applications, 15(4): 1169-1177.

Motta-Díaz, A.; Nieto, C. \& Aranguren-Riaño, N.J. 2012. New reports of the genus Baetodes Needham and Murphy (Ephemeroptera: Baetidae) from Colombia. Entomotropica, 27: 45-47.

Oksanen, J.; Blanchet, F.G.; Friendly, M.; Kindt, R.; Legendre, P.; McGlinn, D.; Minchin, P.R.; O'Hara, R.B.; Simpson, G.L.; Solymos, P.; Stevens, M.H.H.; Szoecs, E. \& Wagner, H. 2019. vegan: Community Ecology Package. R package version 2.5-6. https://CRAN.R-project.org/package=vegan.

Osorio-Ramírez, D.P.; Díaz-Celis, 0.J.; Caro-Caro, C.I. \& Duque-Cabrera, J. 2015. Generalidades del área de estudio. In: Torres-Mora, M.A.; CaroCaro, C.I.; Ramírez-Gil, H.; Parada-Guevara, S.L.; Trujillo-González, J.M.; Ajiaco-Martínez, R.E.; Osorio-Ramírez, D.P. \& Díaz-Celis, 0.D. (Eds.). Cuenca alta del río Meta: una mirada socioambiental a los ríos Guayuriba y Ocoa y al caño Quenane-Quenanito. Meta, Universidad de los Llanos. p. 12-65.

Pacheco, J.; Pat, R. \& Cabrera, A. 2002. Análisis del ciclo del nitrógeno en el medio ambiente con relación al agua subterránea y su efecto en los seres vivos. Ingeniería, 6: 73-81.

Peres-Neto, P.R.; Legendre, P.; Dray, S. \& Borcard, D. 2006. Variation partitioning of species data matrices: estimation and comparison of fractions. Ecology, 87(10): 2614-2625.

Prat, N.; Ríos, B.; Acosta, R. \& Rieradevall, M. 2009. Los macroinvertebrados como indicadores de calidad de las aguas. In: Domínguez, E. \& Fernández, H. (Eds.). Macroinvertebrados bentónicos sudamericanos. Sistemática y biología. Tucuman, Fundación Miguel Lillo. p. 631-654.

Ramírez, A. \& Viña, G. 1998. Limnología colombiana. Bogotá, Fundación Universidad Jorge Tadeo Lozano. 
Ramírez, A.; Restrepo, R. \& Viña, G. 1997. Cuatro índices de contaminación para caracterización de aguas continentales, formulaciones y aplicación. CT \& F-Ciencia, Tecnología Y Futuro, 1: 135-153.

Reynaga, M.C. \& Dos Santos, D.A. 2012. Rasgos biológicos de macroinvertebrados de ríos subtropicales: patrones de variación a lo largo de gradientes ambientales espacio-temporales. Ecología Austral, 22(2): 112-120.

Rojas, A.M.; Baena, M.L.; Serrato, C.; Caicedo, G. \& Zúñiga, M. Del C. 1993. Clave para las familias y géneros de ninfas de Ephemeroptera del departamento del Valle del Cauca, Colombia. Boletín del Museo de Entomología de La Universidad Del Valle, 1: 33-45.

Roldán, G. \& Ramírez, J.J. 2008. Fundamentos de limnología neotropical, 2. ed. Medellín, Editorial Universidad de Antioquia.

Rozo, M.P. \& Salinas, L.G. 2016. Inventario del orden Ephemeroptera (Insecta) en la quebrada Coquital, Serranía de Tripogadí, Departamento del Chocó, Colombia. Entomotropica, 31: 1-13.

RStudio Team (2015). RStudio: Integrated Development for R. Boston, RStudio. http://www.rstudio.com.

Salinas, L.G.;Dias, L.; Bacca, T.; Zúñiga, M. Del C. \& Rodríguez, M. 2012. Primeros registros de Ephemeroptera (Insecta) para el departamento de Putumayo, Colombia. Boletín Científico de Museo de Historia Natural, 16(2): 198-208.

Salinas, L.G.; Dias, L.; Salles, F.F. \& Bacca, T. 2011. Three new species of Baetodes Needham y Murphy (Ephemeroptera: Baetidae) from Colombia. Zootaxa, 3110: 61-68.

Salinas, L.G.; Flowers, R.W. \& Dias, L. 2013. First record of Hydrosmilodon primanus (Eaton) (Ephemeroptera, Leptophlebiidae) from South America. Biota Neotropica, 13: 363-365.

Salinas-Jiménez, L.G.; Boldrini, R.; Osorio-Ramírez, D.P.; Caro, C.I. \& RojasPeña J.I. 2019. A new species of Camelobaetidius Demoulin, 1966 (Ephemeroptera: Baetidae), from the Colombian Orinoco River basin. Zootaxa, 4656: 367-374.

Salinas-Jiménez, L.G.; Rojas-Peña, J.l.; Osorio-Ramírez, D.P. \& Caro-Caro, C.I. 2017. New records of Ephemeroptera from the Colombian Orinoco river basin of the Meta department. Revista Colombiana de Entomología, 43: 271-276.

Salinas-Jiménez, L.G.; Suárez-Mantilla, E.Y.; Orejarena-Cuartas, J.A. \& TorresMora, M.A. 2018. Primer registro de la ninfa de Fittkaulus amazonicus Kluge (Ephemeroptera, Leptophlebiidae) para Colombia y ampliación de la distribución a la cuenca del río Orinoco. Boletín Científico Centro de Museos. Museo de Historia Natural Universidad de Caldas, 22: 97-101.

Salles, F.F.; Molineri, C.; Nieto, C.; Lima, L.R.C.; Dias, L.C.; Boldrini, R.; Mariano, R. \& Domínguez, E. 2020. Ephemeroptera da América do Sul. Versión 07 abril 2020. Available: http://ephemeroptera.com.br. Access: 21/06/2020.

Savić, A.; Ranđelović, V.; Branković, S. \& Krpo-Ćetković, J. 2011. Mayfly (Insecta: Ephemeroptera) community structure as an indicator of the ecological status of the Nišava river (Central Balkan Peninsula). Aquatic Ecosystem Health and Management, 14(3): 276-284.

Sharifinia, M.; Mahmoudifard, A.; Imanpour Namin, J.; Ramezanpour, Z. \& Yap, C.K. 2016. Pollution evaluation in the Shahrood River: Do physico- chemical and macroinvertebrate-based indices indicate same responses to anthropogenic activities? Chemosphere, 159: 584-594.

Shimano, Y.; Juen, L.; Salles, F.F.; Nogueira, D.S. \& Cabette, H.S.R. 2013. Environmental and spatial processes determining Ephemeroptera (Insecta) structures in tropical streams. Annales de Limnologie International Journal of Limnology, 49: 31-41.

Souto, R.M.G.; Facure, K.G.; Pavanin, L.A. \& Jacobucci, G.B. 2011. Influence of environmental factors on benthic macroinvertebrate communities of urban streams in Vereda habitats, Central Brazil. Acta Limnologica Brasiliensia, 23(3): 293-306.

Springer, M. 2010. Capítulo 3: Biomonitoreo acuático. Journal of Tropical Biology, 58: 53-59.

Tanaka, M.0.; Teixeira De Souza, A.L.; Moschini, L.E. \& Kannebley De Oliveira, A. 2016. Influence of watershed land use and riparian characteristics on biological indicators of stream water quality in southeastern Brazil. Agriculture, Ecosystems and Environment, 216:333-339.

Vinasco-Mondragón, F. \& Zúniiga, M. Del C. 2016. Primeros registros de Callibaetis radiatus y C. viviparus (Ephemeroptera: Baetidae) para Colombia. Revista Colombiana de Entomología, 42: 91-94.

World Water Assessment Programme (WWAP). 2017. The United Nations World Water Development Report 2017. Wastewater: The Untapped Resource. Paris, UNESCO.

Zaiontz, C. 2020. Real Statistics Using Excel (Release 6.8). http://www.realstatistics.com.

Zamora, H. 2015. Macroinvertebrados acuáticos registrados durante la época de lluvias en tres ríos del piedemonte llanero de Colombia. Revista Colombiana de Ciencia Animal, 7: 139-147.

Zedková, B.; Rádková, V.; Bojková, J.; Soldán, T. \& Zahrádková, S. 2014. Mayflies (Ephemeroptera) as indicators of environmental changes in the past five decades: A case study from the Morava and Odra River Basins (Czech Republic). Aquatic Conservation: Marine and Freshwater Ecosystems, 25(5): 483-499.

Zúñiga, M. Del C. \& Torres-Zambrano, N.N. 2015. Tricorythopsis rondoniensis (Dias, Salles \& Fereira) (Insecta: Ephemeroptera: Leptohyphidae): Nuevo registro de distribución para Colombia y la cuenca del río Orinoco. Dugesiana, 22: 37-38.

Zúñiga, M. Del C.; Cardona, W.; Molineri, C.; Mendivil, J.; Cultid, C.; Chará, A.M. \& Giraldo, A. 2014. Entomofauna acuática del Parque Nacional Natural Gorgona, Pacífico colombiano, con énfasis en Ephemeroptera y Plecoptera. Revista de Biología Tropical, 62(Suppl. 1): 221-241.

Zúñiga, M. Del C.; Molineri, C.; Domínguez, E. \& Cardona, W. 2015. Leptophlebiidae (Insecta: Ephemeroptera) from Gorgona Island National Natural Park (Tropical Eastern Pacific, Colombia) with the description of two new species. Annales de Limnologie - International Journal of Limnology, 51: 281-296.

Zúníiga, M. Del C.; Rojas De Hernández, A.M. \& Mosquera De Aguilera, S. 1997. Biological aspects of Ephemeroptera in rivers of southwestern Colombia (South America). In: Landolt, P. \& Sartori, M. (Eds.). Ephemeroptera y Plecoptera: biology-ecology-systematics. Fribourg, MTL. p. 261-269. 